\title{
Management of Type II Odontoid Fractures for Osteoporotic Bone Structure: Preliminary Report
}

\author{
Osteoporotik Kemik Yapusuna Sabip Tip 2 Odontoid Kiruklarmun Tedavisi: \\ Ön Rapor
}

Murat COSAR ${ }^{1}$, A Fahir OZER ${ }^{2}$, Bahadır ALKAN ${ }^{1}$, Mustafa GUVEN $^{1}$, Tarik AKMAN ${ }^{1}$, Adem Bozkurt ARAS ${ }^{1}$, Davut CEYLAN ${ }^{3}$, Mehmet TOKMAK ${ }^{4}$

${ }^{1}$ Canakkale 18 Mart University, School of Medicine, Department of Neurosurgery, Canakkale, Turkey

${ }^{2}$ Koc University, School of Medicine, Department of Neurosurgery, Istanbul, Turkey

${ }^{3}$ Sakarya University, School of Medicine, Department of Neurosurgery, Sakarya, Turkey

${ }^{4}$ Medipol University, School of Medicine, Department of Neurosurgery, Istanbul, Turkey

Corresponding Author: Murat COSAR / E-mail: drcosar@hotmail.com

\begin{abstract}
AIM: Anterior transodontoid screw fixation technique is generally chosen for the management of type ll odontoid fractures. The nonunion of type II odontoid fractures is still a major problem especially in elderly and osteoporotic patients. Eleven osteoporotic type II odontoid fracured patients were presented in this article.

MATERIAL and METHODS: We have divided 11 patients in two groups as classical and Ozer's technique. We have also compared (radiologically and clinically) the classical anterior transodontoid screw fixation (group II: 6 cases) and Ozer's transodontoid screw fixation technique (group I: 5 cases) retrospectively.

RESULTS: There was no difference regaring the clinical features of the groups. However, the radiological results showed $100 \%$ fusion for Ozer's screw fixation technique and $83 \%$ fusion for the classical screw fixation technique.

CONCLUSION: In conclusion, we suggest that Ozer's technique may help to increase the fusion capacity for osteoporotic type II odontoid fractures.
\end{abstract}

KEYWORDS: Cervical, Fracture, Odontoid fractures, Osteoporosis, Pseudoarthrosis

öz

AMAÇ: Anterior transodontoid vida fiksasyon tekniği tip 2 odontoid kırıklarında genellikle seçilen yöntemdir. Tip 2 odontoid kırıklarında özellikle yaşlı ve osteoporotik hastalarda kaynamama halen önemli bir problemdir. Yazımızda 11 adet osteoporotik tip 2 odontoid kırık olgusu sunulmuştur.

YÖNTEM ve GEREÇLER: On bir hasta klasik ve Özer tekniği şekilde ikiye ayrıldı. Klasik vida fiksasyon tekniği ( $n=6)$ ve Özer'in vida fiksasyon tekniği ile opere edilen hastalar $(n=5)$ geriye dönük olarak radyolojik ve klinik olarak karşılaştırıldı.

BULGULAR: Klinik değerlendirmede, gruplar arasında fark yoktu. Ancak radyolojik değerlendirmede Özer'in vida fiksasyon tekniği \%100 füzyon gösterirken, klasik vida fiksasyon tekniği \%83 füzyon göstermekte idi.

SONUÇ: Sonuç olarak, Özer tekniğinin osteoporotik tip 2 kırıklarında füzyon kapasitesini artırmaya yardımcı olduğunu öne sürebiliriz.

ANAHTAR SÖZCÜKLER: Servikal, Kırık, Odontoid kırıkları, Osteoporoz, Psödoartroz

\section{INTRODUCTION}

The odontoid fractures are specific fractures of upper cervical vertebra and also need to behave with speciality of the fractured case $(1,2)$. Fractures are classified into three subgroups and type II fractures, including the odontoid, make up $60 \%$ of them. Type II and surface type III fractures are recognized as unstable and have a $6 \%$ risk of morbidity and mortality (3-7).

Orthoses or halo stabilization and jacket are recommended for stable conservative treatment of cervical odontoid fractures. Anterior or posterior surgical techniques were used for the stabilization and/or fusion of fractured odontoid pieces. Minimally invasive surgical approaches are suggested for the treatment of unstable odontoid fractures (5). Anterior percutaneous procedures have also been added to the fixation of the odontoid, especially in the last 10 years $(2,3)$.

Despite these developments for the surgical management of odontoid fractures, nonunion is still a major problem. The literature knowledge demonstrate that the rate of nonunion increases up to $30 \%$ in some series complicated with advanced patient age, extent of neurological damage, 
degree of dense displacement, presence of concomitant C1-2 fracture, preexisting pathologic condition, and age of the fracture $(4,6,8-10)$.

In our previous study, we have reported a new surgical transodontoid screw fixation technique for delayed type II odontoid fractures (4). We prepared the sclerotic surfaces of fractured parts for fusion and also we showed that preparation prevented nonunion and/or pseudoarthrosis. In this study, we want to focus on the osteoporotic cases those admitted with acute type II odontoid fractures. We present 11 osteoporotic cases with type II odontoid fracture that were operated with two different anterior fixation techniques. Five of the cases were treated with Ozer's anterior transodontoid screw fixation technique while the remaining 6 cases were operated with the classical anterior transodontoid screw fixation technique at Canakkale 18 Mart University Hospital and VKV American Hospital by two surgeons.

\section{MATERIAL and METHODS}

Eleven cases of osteoporotic acute type II odontoid fractures admitted to the hospital after trauma between 2009 and 2012. Five of the 11 cases were operated on with Ozer's anterior transodontoid screw fixation technique (group I) while the remaining 6 cases were operated with the classical anterior transodontoid screw fixation technique (group II). The mean age of the group I was 68 years (range, 55 to 80 years) with a female majority ( 2 males and 3 females). The mean age of group II was 70 years (range, 58 to 79 years) with an equal female-male ratio ( 3 males and 3 females). The osteoporotic evaluation of the groups was conducted with dual photon $x$-ray absorptiometry (DEXA) before and/or after the surgery.

Ozer et al. (4) reported a specific anterior transodontoid screw fixation technique for the management of chronic type II odontoid fractures. A 2-mm threaded K-wire is inserted into the fractured odontoid bone. The K-wire was left in place for the fixation of fractured odontoid. After this process, another K- wire was used to create multiple entry points into the odontoid from the right and left side of the fixed K-wire (controlled under biplanar fluoroscopy). Multiple holes were therefore created in the sclerotic margins of the C2 body, and the odontoid and these holes provided more contact points of spongious bone to spongious bone (Figure 1).

Motor vehicle accidents ( 1 cases) and falls (4 cases) caused all of the injuries in-group l, while 75 percent of the cases (falls: 3 cases, motor vehicle accidents: 1 case) were due to falls ingroup II. All lesions in both groups were found to be unstable after radiological investigation.
The odontoid bony fragment was displaced ventrally in 2 cases (40\%), dorsally in 2 cases (40\%), and remained in the natural anatomic position in 1 cases (20\%) in group I. Three of the 6 cases were located anteriorly and the rest ones were located posteriorly in group II.

The Frankel scale was used for the neurological evaluation of all cases. The mean follow up period was 18 months in-group I and 20 months in-group II. A single screw was placed for both groups and a cervical collar was used for 3 months.

\section{RESULTS}

The clinical data of the patient group are presented in Table I. In our series, 5 of the 11 osteoporotic type II odontoid fracture patients were operated on via Ozer's trans-odontoid screw fixation technique (group I). The second group was operated with the classical trans odontoid screw fixation technique.

In group I, we did not observe any vascular injury, screw malposition, nonunion, infection, mortality, and morbidity for the mean 18 months follow-up period. In-group II, we found non-union in one case (20\%) and did not observe any vascular injury, screw malposition, infection, mortality, and morbidity for the mean 20 months follow-up period.

The neurological status of the patients in both groups was evaluated with Frankel scores and did not change in the follow-up period (Table I).

The preoperative and postoperative radiological images of selected cases for both groups are shown in Figure 2A, B and Figure 3A, B.

\section{DISCUSSION}

The treatment modalities of type II odontoid fractures range from conservative therapy to surgical options. The difficulty of spontaneous fusion and the pseudoarthrosis risk are common problems in type II odontoid fractures. Conservative therapy such as halo bracing can be chosen for the young patients but it also carries a nonunion risk with pain, infection at the pin sites, osteomyelitis of the skull, and risk of social problems $(4,8,9,11,12)$. These problems popularized the surgical options for the management of type II odontoid fractures $(4,6)$. Percutaneous and endoscopic approach of transodontoid screw fixation techniques were also developed and performed successfully $(3,5,10,11)$.

Despite the success of the transodontoid screw fixation technique, the rate of nonunion problems and the pseudoarthrosis risk are still high in chronic and elderly type II fractured patients and may rise to $30 \%$ in some clinical series

Table I: The Demographic and Clinical Data of Both Groups

\begin{tabular}{|c|c|c|c|c|c|c|c|} 
& Age (Y) & Sex (m/f) & $\begin{array}{c}\text { Time to } \\
\text { Admission (d) }\end{array}$ & $\begin{array}{c}\text { Neurological } \\
\text { Status }\end{array}$ & $\begin{array}{c}\text { Hospitalization } \\
\text { Period (d) }\end{array}$ & $\begin{array}{c}\text { Follow up } \\
\text { period (m) }\end{array}$ & $\begin{array}{c}\text { Outcome } \\
\text { Group I (n: 5) }\end{array}$ \\
\hline 68 & $2 / 3$ & 2 & $E$ & 2.5 & 18 & E \\
\hline Group II (n: 6) & 70 & $3 / 3$ & 3 & $E$ & 3 & 20 & $E$ \\
\hline
\end{tabular}

m/f: male/female, d: day, $\boldsymbol{m}:$ month, $\boldsymbol{Y}:$ year, E: normal (ASIA impairment scale) 
$(12,13)$. Age, distance between the fractured parts and sclerotic margins of the fracture sites are generally claimed for the reason of the nonunion $(7,8)$. The prevalence of osteoporosis in male and female patients over 50 years old is $14.5 \%$ and $51.3 \%$ respectively for spine related patients (14-18). Beside these common reasons, degenerative changes in the atlantoodontoid joint, severity of osteoporosis in the odontoid process, posterior oblique fracture type, sub-optimal fracture reduction, sub-optimal position of implant, quality of fracture compression and severity of fracture comminution may also effect the healing of the odontoid fracture $(13-16,19)$.

In 2009, Ozer etal. (4) reported a specific anterior transodontoid screw fixation technique for the management of chronic type II odontoid fractures. They created multiple holes in the sclerotic margins of the C2 body and the odontoid. These holes provided more contact points of spongious bone to

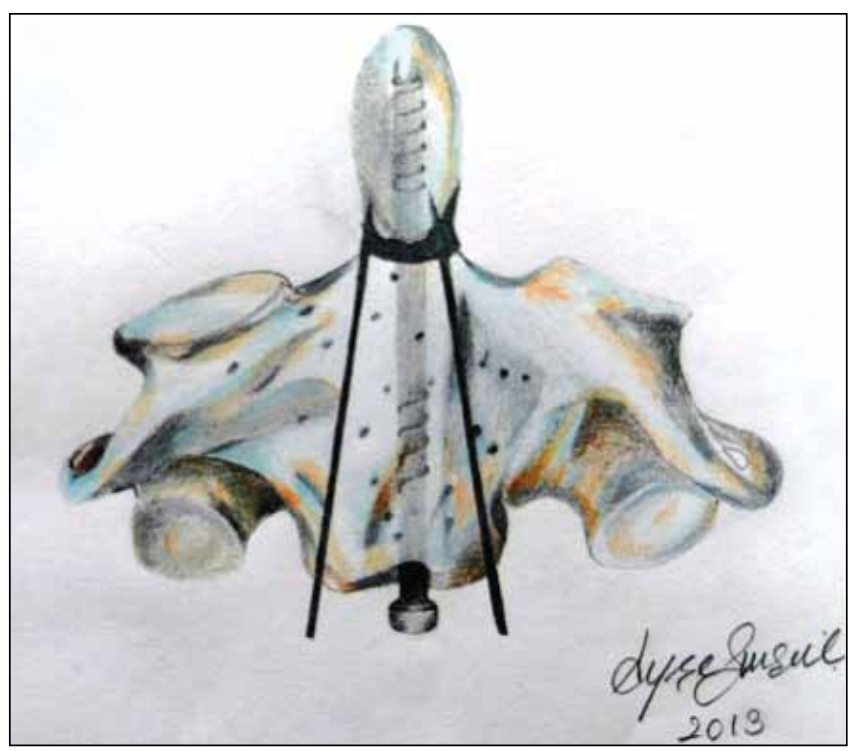

Figure 1: Illustration showing the technique of operation. spongious bone. They reported four type Il odontoid fractured cases, which were treated successfully with this technique (4).

We have thought over the technique of Ozer's et al. and decided that this technique may help to increase the healing potential of osteoporotic odontoid type II fractures. We have operated suitable cases with this technique in two different hospitals. We have performed single odontoid screw for the anterior trans-odontoid stabilization of the type II fractures. After three years, we have collected all of our 11 osteoporotic odontoid type II fractured cases retrospectively and divided them into 2 groups. The first group was operated with Ozer's technique while the second group was operated with the classical anterior transodontoid screw fixation technique.

We think that the K-wire insertion into the surface of the fractured part of the odontoid may help to trigger the osteoblasts. Osteoblastogenesis potential of the fractured bone may therefore increase (20). We think that this trigger procedure with K-wire is better than performing double transodontoid screw fixation for osteoporotic type ll odontoid fractures. This procedure must be supported with anabolic medical treatments such as biphospanates, parathormone, etc.

Although, our clinical odontoid type II fracture series is limited, the comparison of both groups showed that Ozer's technique is more effective for the fusion of fractured sites. We think that the K-wire, which is introduced into the fractured parts via the different points, may trigger the osteocytes at the spongious part. The triggered osteocytes contribute to form callus at the fractured sites.

In our series, all of the patients (100\%) who were operated with Ozer's technique showed fusion after six months. The fusion rate was higher than in the second classical group (83\%). We did not observe neurovascular damage, infection, and instrument-based problems etc. in either group. All of the patients in both groups were fused with a single screw. The patients of both groups have used a cervical collar for 3 months after the surgery.
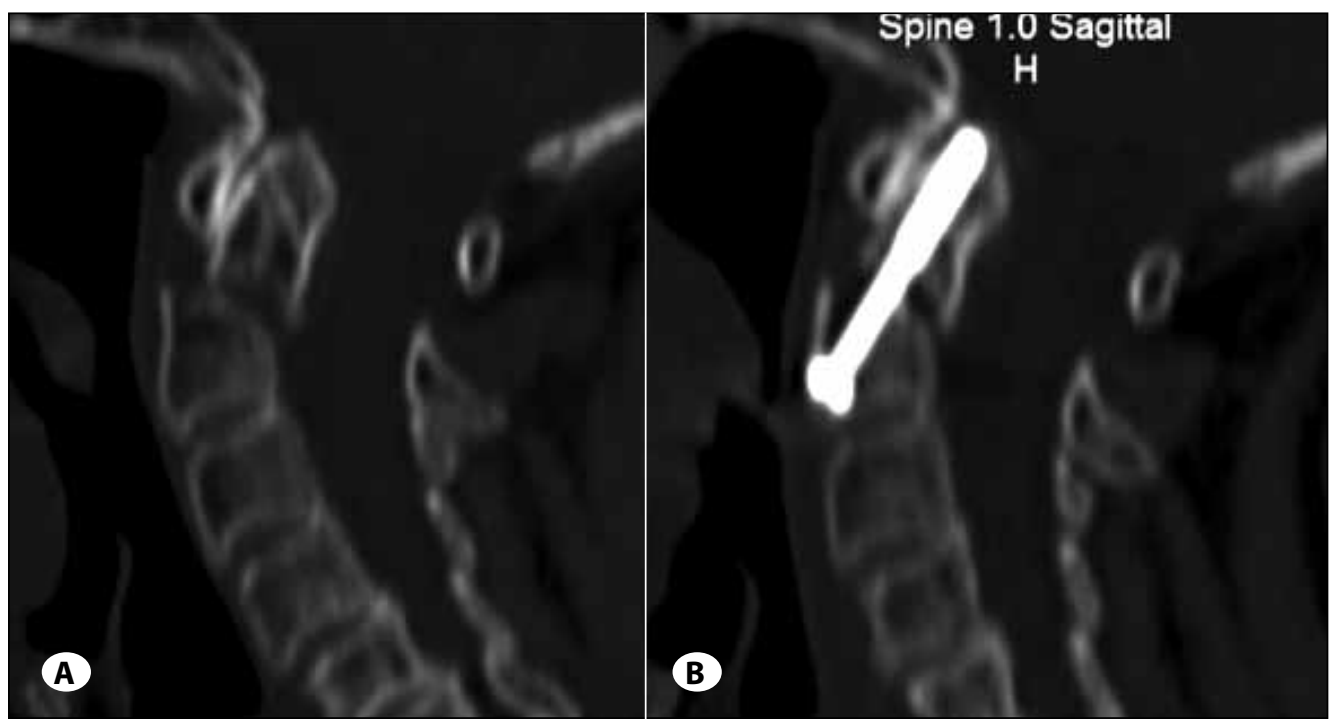

Figure 2:

A) Preoperative and B) postoperative $3^{\text {rd }}$ month CT showing the odontoid fracture type II and fusion (Group I). 


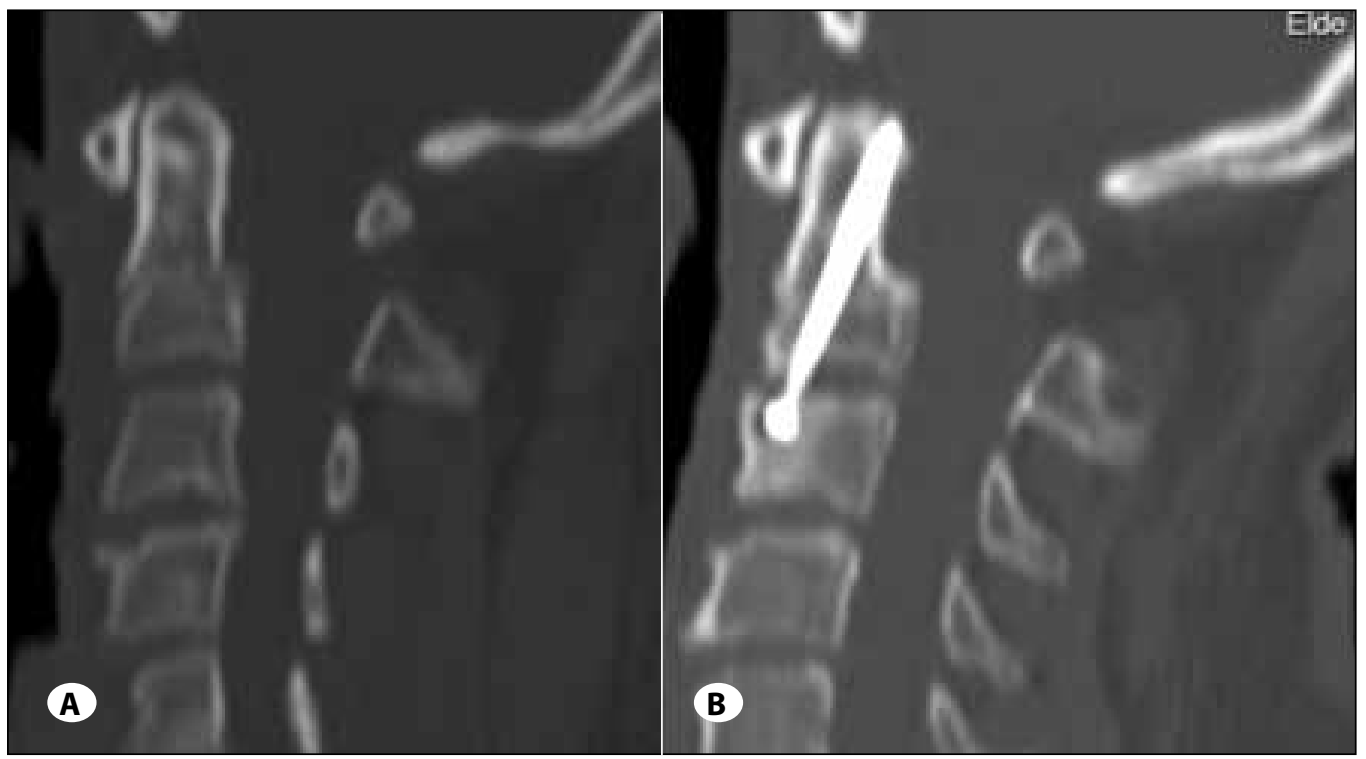

Figure 3:

A) Preoperative and B) postoperative $6^{\text {th }}$ month $\mathrm{CT}$ showing the odontoid fracture type II and fusion (Group II).
Although our number of patients is limited and we need larger series, we think that the Ozer's anterior transodontoid screw fixation technique may help to increase the healing capacity of fractured sites of type II fracture. This technique may be chosen for the suitable patients for the fusion of type Il odontoid fractures.

\section{REFERENCES}

1. Anderson L: Fractures of the odontoid process of the axis. In: Bailey R Sher H, Dunn E (eds), The Cervical Spine. Philedelphia: JB Lippincott, 1983:206-223

2. Apfelbaum RI: Screw fixation for type II odontoid fractures. In: Al- Mefty O, Origitano TC, Harkey HL (eds), Controversies in Neurosurgery. New York: Thieme Medical Publishers, 1996:287-291

3. Apuzzo MLJ, Heiden JS, Weiss MH, Ackerson TT, Harvey JP, Kurze T: Acute fractures of the odontoid process. An analysis of 45 cases. J Neurosurg 48: 85-91, 1978

4. Berlemann U, Schwarzenbach O: Dens fractures in the elderly. Results of anterior screw fixation in 19 elderly patients. Acta Orthop Scand 68(4): 319-324, 1997

5. Ceylan D, Hatiboglu MA, İplikcioglu AC, Basocak K, Cosar M, Gokduman CA: Tip II odontoid kırıklarının tedavisi. Türk Nöroşir Derg 15: 279-284,2005

6. Chi YL, Wang XY, Xu HZ, Lin Y, Huang OS, Mao FM: Management of odontoid fractures with percutaneous anterior odontoid screw fixation. Eur Spine J 16: 1157-1164, 2007

7. Cosar M: Anterior percutaneous stabilization of odontoid fractures. Türk Nöroşir Derg 19(3):123-126,2009

8. Dunn ME, Seljeskog EL: Experience in the management of odontoid process injuries. An analysis of 128 cases. Neurosurgery 18: 306-310, 1986

9. Kazan S, Tuncer R, Sindel M: Percutaneous anterior odontoid screw fixation technique: A new instrument and a cadaveric study. Acta Neurochir (Wien) 141: 521-524,1999
10. Lakshmanan P, Jones A, Howes J, Lyons K: CT evaluation of the pattern of odontoid fractures in the elderly - relationship to upper cervical spine osteoarthritis. Eur Spine J 14: 7883,2005

11. Luo $P$, Dou HC, Ni WF, Huang QS, Wang XY, Xu HZ, Chi YL: Application of anterior percutaneous screw fixation in treatment of odontoid process fractures in aged people. Zhongguo Gu Shang 24(3): 227-230, 2011

12. Neugebauer R: Tissue-preserving ventral compression osteosynthesis of dens axis fractures using endoscopy and special instruments. Unfallchirurg 94: 313-316, 1991

13. Osti M, Philipp H, Meusburger B, Benedetto KP: Analysis of failure following anterior screw fixation of Type II odontoid fractures in geriatric patients. Eur Spine J 20:1915-1920,2011

14. Ozer AF, Cosar $M$, Oktenoglu TB, Sasani $M$, Iplikcioglu AC, Bozkus $H$, Sarioglu AC: A new transodontoid fixation technique for delayed type II odontoid fracture: Technical note. Surg Neurol 71(1): 121-125, 2009

15. Park SB, Chung CK: Strategies of spinal fusion on osteoporotic spine. J Korean Neurosurg Soc 49: 317-322,2011

16. Scholz M, Schnake KJ, Hoffmann R, Kandziora F: Cementaugmented anterior odontoid screw fixation of a AndersonD'Alonzo type II fracture with massive osteoporosis. Case report. Z Orthop Unfall 149(3): 308-311, 2011

17. Seybold EA, Bayley JC: Functional outcome of surgically and conservatively managed dens fractures. Spine 23(17):18371846, 1998

18. Stoney J, O'Brien J, Wilde P: Treatment of type-two odontoid fractures in halothoracic vest. J Bone Joint Surg Br 80(3): 452455,1998

19. Stulík J, Sebesta P, Vyskocil T, Kryl J: Fractures of the dens in patients older than 65 years: Direct osteosynthesis of the dens versus C1-C2 posterior fixation. Acta Chir Orthop Traumatol Cech 75(2): 99-105, 2008

20. Sucu HK, Akkol I, Minoglu M, Gelal F: Percutaneous anterior odontoid screw fixation. Minim Invasive Neurosurg 51: 106-108, 2008 